Original Research Paper

\title{
The Effect of Electricity Price on Saving Energy Transmitted from External Building Walls
}

\author{
Samah K. Alghoul, Ammar O. Gwesha and Abdurrauf M. Naas \\ Department of Mechanical and Industrial Engineering, University of Tripoli, Tripoli, Libya
}

\author{
Article history \\ Received: 14-05-2016 \\ Revised: 17-05-2016 \\ Accepted: 31-05-2016 \\ Corresponding Author: \\ Samah K. Alghoul \\ Department of Mechanical and \\ Industrial Engineering, \\ University of Tripoli, Tripoli, \\ Libya \\ Email: s.alghoul@uot.edu.ly
}

\begin{abstract}
Space heating and cooling loads consume a significant part of the national produced energy in many countries. Therefore, substantial energy savings can be achieved by the reduction of spent energy in this category. Since wall insulation is rarely used in Libya, this research was conducted to study the effect of electricity price on residential heating and cooling energy consumption and on the insulation thickness. In addition, the study aims to trigger the problem of the huge energy losses due to space cooling and heating and to estimate potential savings. Degree-days values were used to estimate the amount of annual heating and cooling required per meter square of wall. The life-cycle cost analysis was used to estimate the optimum insulation thickness. The city of Tripoli, located in Libya's Mediterranean coast was used as a case study. The results showed that the amount of annual energy savings could reach $16.9 \mathrm{kWh}$ per meter square, with life cost savings of 46.1 \$ per meter square. The study also showed that the current subsidized price of electricity does not encourage individuals to save energy by using thermal insulation in building walls. However, the amount of potential energy saving on a national scale is significant when considering the actual electricity price. It is estimated for a community of 10000 houses by about 67.7 million dollars.
\end{abstract}

Keywords: Electricity Price, Insulation Thickness, Optimization, Building Walls, Energy Savings

\section{Introduction}

The growing demand for energy is globally rising as the world population increases and the improvements of living standards are sought. The residential sector is considered to account for highest portion of the total energy consumption (Al-Homoud, 2005; Ghrab-Morcos, 2005; Wang et al., 2007). For instance, in Libya the residential sector consumed about $39 \%$ of the total production capacity of 5,981 MW in 2012. The nationwide energy demand is projected to reach $48,497 \mathrm{GWh}$ by 2017 compared to $22,980 \mathrm{GWh}$ in 2012 . Figure 1 shows the percentage of energy consumption for different categories in Libya (GECOL, 2012).

One of the most effective ways to save energy and achieve environmental objectives and our aspiration for a better quality of life is to apply thermal insulations on external walls of buildings. This will decrease energy consumption on space heating and cooling loads owing to heat transmission through the building envelope. Numerous research has been conducted to determine the optimum thickness of insulation at which the cost of both energy consumption and the insulation is minimized over the estimated lifetime of the insulation.

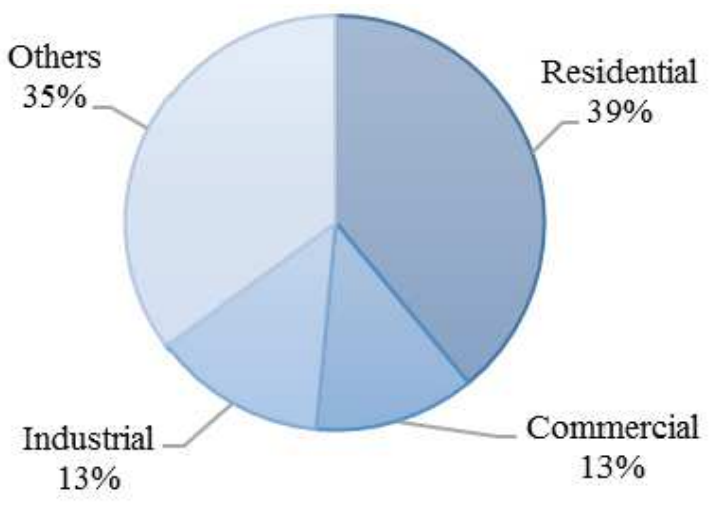

Fig. 1. Percentage of energy consumption in Libya in 2012 
In most studies, the method of Life Cycle Cost analysis (LCC) based on the degree-days or degree-hours values was performed to optimize the thickness of insulation under static conditions. Hasan (1999) determined the optimum thickness of insulation using LCC. The results showed that the payback periods for polystyrene and rock wool were 1.3-2.3 years and 1-1.7 years, respectively. Al-Sallal (2003) analyzed two types of roof insulations in warm climate and cold climate locations in the USA. His comparison reported that the payback period in the cold climate zone is shorter than that of warm climate. Sixteen cities from different climate regions of Turkey were studied by Bolattürk (2006). Depending on the type of fuel used in cooling/heating and the city, the results showed that the optimum thickness of insulation ranged from 2 to $17 \mathrm{~cm}$ and the energy savings varied between 22 and $79 \%$ with 1.3-4.4 years of payback periods. In China, Yu et al. (2009) selected four cities repressing different climate zones to optimize the thickness of five types of insulation. They concluded that using expanded polystyrene as an insulation material is more efficient than other types considered in their study. Gwesha et al. (2016) selected three cities repressing different climate zones to optimize the thickness of various types of insulation. The results agree with $\mathrm{Yu}$ et al. (2009) since expanded polystyrene found to be the best insulation material. Al-Sanea et al. (2005) studied the effect of electricity tariff on the optimum thickness of insulation using a numerical model based on the finite volume method and an economic model based on LCC analysis. They determined the optimum thickness of insulation in Riyad (The capital of Saudi Arabia) using expanded polystyrene for five different average electricity tariffs.

Several studies were carried out to investigate the most suitable position to place an insulation layer for walls and/or roofs. Asan (2000) numerically conducted investigations that were applied on $4 \mathrm{~cm}$ thick of insulation along with a $20 \mathrm{~cm}$ thick wall. The results showed that the most practical configuration among six different scenarios is to place half of the insulation in the middle of the wall and the other half on the outside of the wall. Ozel and Pihtili (2007a; 2007b) extended the cases analyzed by Asan to include 12 different configurations. It was concluded that using three layers of insulation; one on the outer surface of the wall, the second one on the inner surface and one in the middle, resulted in obtaining the best thermal performance. Ucar and Balo (2011) investigated four different wall structures. It was reported that the highest amount of energy savings was obtained using a sandwich wall, where the insulation layer was placed in the middle of the wall.

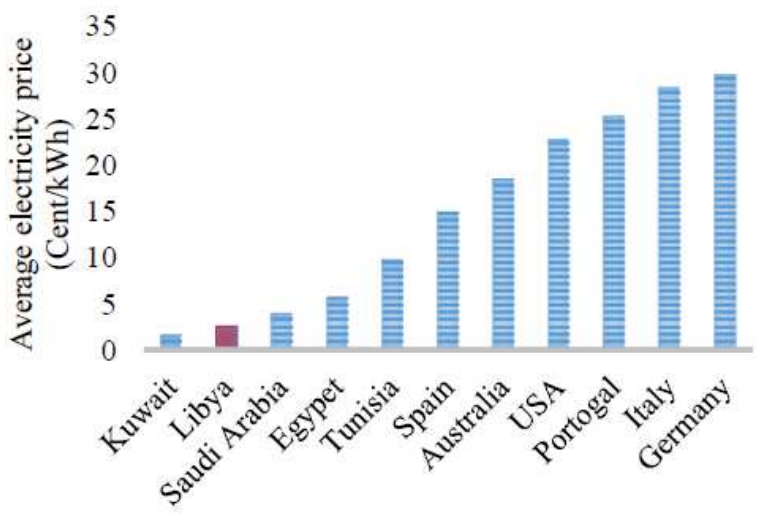

Fig. 2. Average electricity prices in some selected countries

In Libya, the main source of energy used for cooling and heating residential buildings is electricity. The price of electricity is subsidized by the government which is equivalent to $0.015 \$ / \mathrm{kWh}$. This price is very cheap when compared to the price of electricity in other developed and developing countries. Figure 2 shows the average electricity tariffs for some selected countries (Daouas, 2011; Zaed and Agha, 2012; SEC, 2016; SR, 2016).

This present research is aimed to optimize the insulation thickness for external walls under the effect of electricity tariffs in Libya. The capital city of Libya, Tripoli, has been selected for study and the optimization is based on degree-day values of Tripoli and LCC analysis using a sandwich wall. Different electricity prices will be considered in the calculations in order to show the effect of the price on the insulation thickness and consequentially on energy savings.

\section{Wall Construction}

Most of energy loss from buildings is due to the heat loss from walls, roofs, windows, doors and basements. Depending on the results of previous studies (Ucar and Balo, 2011; Gwesha et al., 2016), the wall used in this study consists of five layers where the thermal insulation layer is placed in the middle between two walls of hollow concrete blocks as shown in Fig. 3. Hollow concrete blocks are the most used type in constructing external walls in Libya. Table 1 shows the specifications of different layers that make up the external wall in addition to the values of thermal resistances of the internal and external layers of air.

Degree-days for Tripoli were considered as $558 \mathrm{HDD}$ and $555 \mathrm{CDD}$ assuming the base temperature $18^{\circ} \mathrm{C}$ for Heating and $24^{\circ} \mathrm{C}$ for cooling (Gwesha et al., 2016). These values were calculated from daily temperature records that obtained from the National Centre of Meteorology (NMC, 2014). 
Table 1. Wall construction used in this study (Gwesha et al., 2016; ASHRAE, 1997)

\begin{tabular}{lllll}
\hline Thermal layer & $\mathrm{k}\left(\mathrm{W} / \mathrm{m} .{ }^{\circ} \mathrm{C}\right)$ & $\mathrm{x}(\mathrm{mm})$ & $\mathrm{R}\left(\mathrm{m}^{2} .{ }^{\circ} \mathrm{C} / \mathrm{W}\right)$ & $\rho\left(\mathrm{kg} / \mathrm{m}^{3}\right)$ \\
\hline Inside air & - & - & 0.12 & - \\
Cement plaster & 0.72 & 20 & 0.0278 & 1860 \\
Hollow concrete block & 1.038 & 200 & 0.1927 & 977 \\
Polystyrene insulation & 0.033 & $\mathrm{x}$ & $\mathrm{x} / 0.033$ & 32 \\
Hollow concrete block & 1.038 & 200 & 0.1927 & 977 \\
Cement plaster & 0.72 & 20 & 0.0278 & 1860 \\
Outside air & - & - & 0.044 & - \\
\hline
\end{tabular}

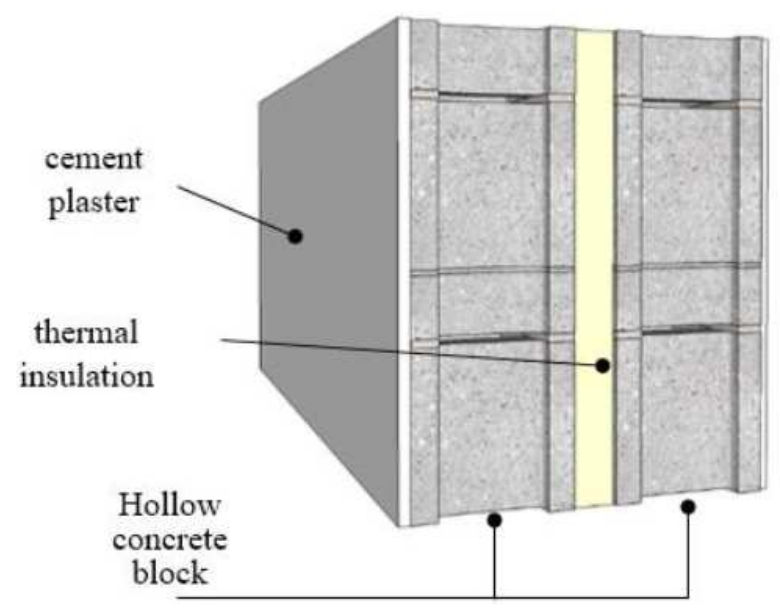

Fig. 3. The main components of the wall

The overall heat transfer coefficient $U$ for the wall described in this study can be defined as:

$$
U=\frac{1}{\left(R_{i}+R_{w}+R_{m}+R_{o}\right)}
$$

where, $R_{w}$ is thermal resistance of the composite wall materials without the insulation, $R_{i}$ and $R_{o}$ are the inside and outside air film thermal resistances, respectively. $R_{\text {in }}$ is the thermal resistance of the insulation. The overall heat transfer coefficient can also be written as:

$$
U=\frac{1}{R_{w t}+\frac{x}{k}}
$$

where, $R_{w t}$ is the total wall thermal resistance excluding the insulation layer $\left(R_{w t}=R_{i}+R_{w}+R_{o}\right)$, $\mathrm{x}$ and $\mathrm{k}$ are the thickness and thermal conductivity of insulation material, respectively.

\section{Annual Heating and Cooling Transmission Loads}

A mathematical model has been presented in order to calculate the amount of energy transmitted through walls, depending on the structure of the wall shown in
Fig. 3. The heat transfers through the wall by three different mechanisms: Conduction, convection and radiation. Solar radiation is absorbed by the outer surface of the wall and then transmits to the inner surface by conduction. The heat transfers also by convection between outside air and the outer surface of wall and between the internal surface of the wall and indoor air. In total, the amount of heat transmission rate through unit area $\left(q, \mathrm{~W} / \mathrm{m}^{2}\right)$ can be calculated by the following equation:

$q=U \Delta T$

where, $U$ is the overall heat transfer coefficient, $\Delta T$ is the difference between the outside and inside design air temperature.

According to building energy standards based on energy performance, it is applicable to assume a $24 \mathrm{~h}$ operation of heat pump with some electric heaters as an auxiliary heating way in winter (Yu et al., 2009). Thus, the amount of heat transmitted annually through the unit area depending on the value of Heating Degree-Days (HDD) in heating season $\left(q_{H}, \mathrm{kWh}\right)$ is expressed by:

$q_{H}=0.024 H D D U$

While the amount of heat transmitted in cooling season $\left(q_{C}, \mathrm{kWh}\right)$ is given by the following equation:

$q_{C}=0.024 C D D U$

In this study a heat pump will be used for heating and cooling a residential space with a Coefficient of Performance (COP) for heating and Energy Efficiency Rating (EER) for cooling.

Therefore, the annual heating energy requirement per unit area can be given as:

$E_{H}=\frac{q_{H}}{C O P}$

and the annual cooling energy requirement per unit area can be written as: 


$$
E_{C}=\frac{q_{C}}{E E R}
$$

Accordingly, the annual heating load $\left(\mathrm{E}_{\mathrm{H}}, \mathrm{kWh} / \mathrm{m}^{2}\right)$ can be estimated by the following equation:

$$
E_{H}=\frac{0.024 H D D}{\left(R_{w t}+\frac{x}{k}\right) C O P}
$$

Similarly, the annual cooling load $\left(E_{C}, \mathrm{kWh} / \mathrm{m}^{2}\right)$ can be determined in a manner analogous to that for heating expression:

$$
E_{C}=\frac{0.024 C D D}{\left(R_{w t}+\frac{x}{k}\right) E E R}
$$

\section{LCC and Optimum Thickness of Insulation}

In order to calculate the optimum thickness of the insulation material, Life-Cycle Cost analysis (LCC) is used in this study. The method depends, in the optimization, on finding the thickness that has a minimum total cost of both insulation material and energy consumed over lifetime period. Therefore, the optimum thickness of the insulation material can be determined by minimizing the total cost or maximizing the life cost saving.

The insulation cost per unit area (Cins, $\left.\$ / \mathrm{m}^{2}\right)$ can be calculated by the following equation:

$$
C_{\text {ins }}=x C_{i}
$$

where, $C_{i}$ is the cost of the insulation material per unit volume $\left(\$ / \mathrm{m}^{3}\right)$. The total cost of energy for heating over the building lifetime is converted to present value by using the Present Worth Factor (PWF) which is defined by the following equation:

$$
P W F=\frac{L T}{(1+i)}, \quad i=g
$$

where, $i$ is the value of the interest rate, $g$ is the inflation rate and $L T$ is the lifetime. Therefore, the life cycle total $\operatorname{cost}\left(C_{T}, \$ / \mathrm{m}^{2}\right)$ of the insulation material and the energy consumption can be calculated by:

$$
C_{T}=\left(E_{H}+E_{C}\right) \times P W F \times C_{E}+C_{i n s}
$$

where, $C_{E}$ is the electricity price $(\$ / \mathrm{kWh})$. The Life Cycle Saving (LCS) is defined as the difference between the value of the saved energy over the lifetime and the total insulation cost and can be calculated by the following equation:

$$
L C S=C_{E}\left[\begin{array}{l}
\left(E_{H}(\text { noins })-E_{H}(\text { withins })\right)+ \\
\left(E_{C}(\text { noins })-E_{C}(\text { withins })\right)
\end{array}\right] P W F-x C i
$$

By differentiating Equation 13 or Equation 14 with respect to the thickness and setting it equal to zero, the following equation for the optimum thickness $\left(x_{\text {opt }}, m\right)$ is obtained:

$x_{\text {opt }}=\left(\frac{0.024 C_{-} E P W F k \cdot D D}{C_{i}}\right)^{\frac{1}{2}} k \cdot R_{w t}$

where, $D D$ is known as the function of climate and energy efficiency of heating and cooling systems, which is defined as:

$D D=C D D / E E R+H D D / C O P$

The total cost of annual energy saving $\left(E A S, \$ / \mathrm{m}^{2}\right)$, using the insulation with the optimum thickness $\left(x_{o p t}\right)$, can be calculated as follows:

$E A S=C_{E}\left[\begin{array}{l}\left(E_{H}(\text { noins })-E_{H}\left(x_{o p t}\right)\right) \\ +\left(E_{C}(\text { noins })-E_{C}\left(x_{o p t}\right)\right)\end{array}\right]$

Assuming the interest rate is equal to the discount rate, the payback period ( $P P$, years) can be obtained as (Yu et al., 2009):

$$
P P=\frac{\left(k R_{w}^{2}+x R_{w t}\right)(i+1) C_{i}}{0.024 C_{E} D D}
$$

\section{Results and Discussion}

The following results are obtained for the external walls of residential buildings at the climatic conditions of the city of Tripoli, located in Libya's Mediterranean coast. The main parameters used to obtain the results are listed in Table 2.

\section{Heating and Cooling Transmission Loads}

Figure 4 shows the annual heating and cooling transmission load per unit area as a function of the insulation thickness. For an uninsulated wall $(x=0)$, the annual values of the cooling and heating loads are 11.6 and $9.7 \mathrm{kWh} / \mathrm{m}^{2}$, respectively. This amount of energy is considerably low when compared to the results of other insulated buildings with severe climatic condition 
(Gürel and Daşdemir, 2011; Çay and Gürel, 2013). However, as the insulation thickness increases, the annual transmission load decreases to about $90 \%$ of the original load as shown in Fig 5. which illustrates the variation of the total load with the insulation thickness. The decrease in loads is sharp at small thicknesses but becomes smoother as the thickness increases. Similar trends were found in the literature with different insulation properties and different climatic conditions (Daouas, 2011; Gürel and Daşdemir, 2011; Çay and Gürel, 2013; Ozel, 2013).

\section{Optimization of Insulation Thickness}

The optimum insulation thickness is studied for five cases with different electricity prices $(0.015$, $0.073,0.146,0.292$ and $0.341 \$ / \mathrm{kWh})$. The first case is the cheapest one, which represents the current price for the electricity in Libya and it is known as the subsidized price. The fifth case reflects the actual estimated cost of electricity in Libya $(0.341 \mathrm{~S} / \mathrm{kWh})$ (Zaed and Agha, 2012). The prices used in the other three cases are in between in order to study the effect of changing the prices. For the subsidized electricity price $(0.015 \$ / \mathrm{kWh})$ the minimum cost of insulation and energy occurs at very small thickness $(0.0005 \mathrm{~m})$ as shown in Fig. 6. This situation leads to the conclusion that there is no insulation needed for the external walls in this case. However, increasing the thickness of the insulation in this case and in all other cases, results in saving more energy as discussed in previous paragraph and as shown in Fig. 4 and 5. Consequently, it is vital to use the actual cost of the electricity to estimate the potential saving of the government expenditure in this sector. By using the actual electricity cost in the analysis $\left(0.341 \$ / \mathrm{m}^{2}\right)$, the insulation thickness is found to be $0.079 \mathrm{~m}$ with insulation cost of $11.67 \$ / \mathrm{m}^{2}$ and energy cost of 14.6 $\$ / \mathrm{m}^{2}$ as shown in Fig. 7. The total savings in this case is about $46.1 \$ / \mathrm{m}^{2}$ as shown in Fig. 8 and the payback period is 2.02 years as shown in Fig. 9.

For other cases, the results of the optimization calculations are summarized in Table 3.

\section{The Effect of Electricity Prices on the Optimum Thickness}

Figure 10 shows the variation of energy consumption cost with the insulation thickness for different electricity prices. The trend of the curves is similar in all cases but with sharper decrease at small thicknesses for higher prices. The savings in energy for the highest electricity price reaches a significant amount of $65 \$ / \mathrm{m}^{2}$ for $20 \mathrm{~cm}$ insulation thickness. As expected, increasing the electricity price towards the actual electricity cost results in higher values of energy savings with increasing the insulation thickness.

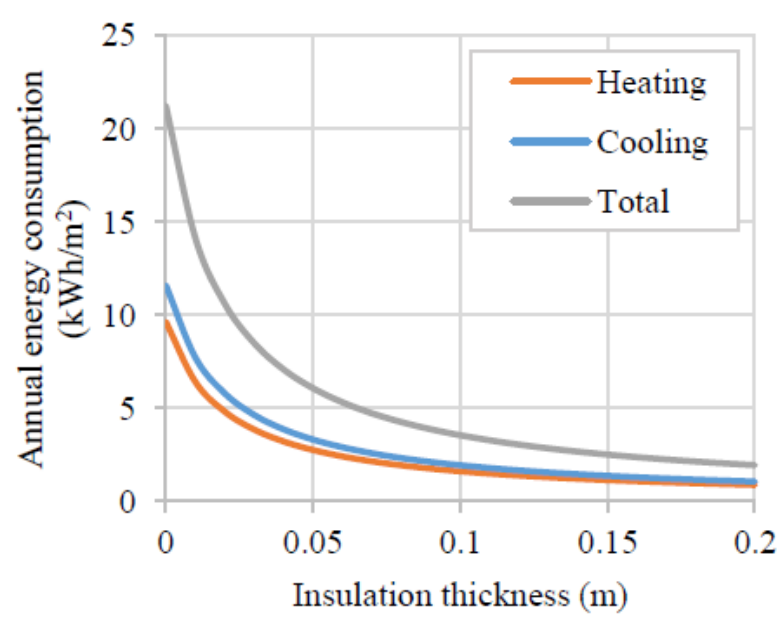

Fig. 4. Annual heating and cooling load versus the insulation thickness

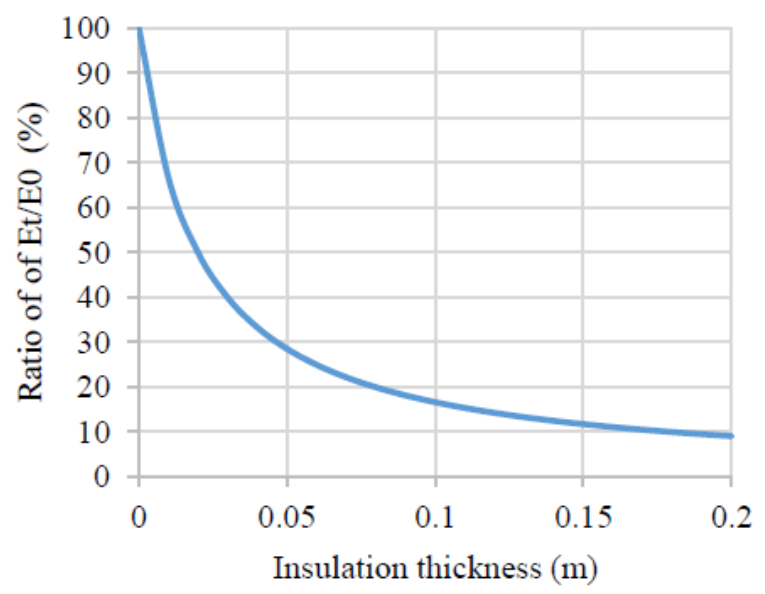

Fig. 5. Total load ratio verses the insulation thickness

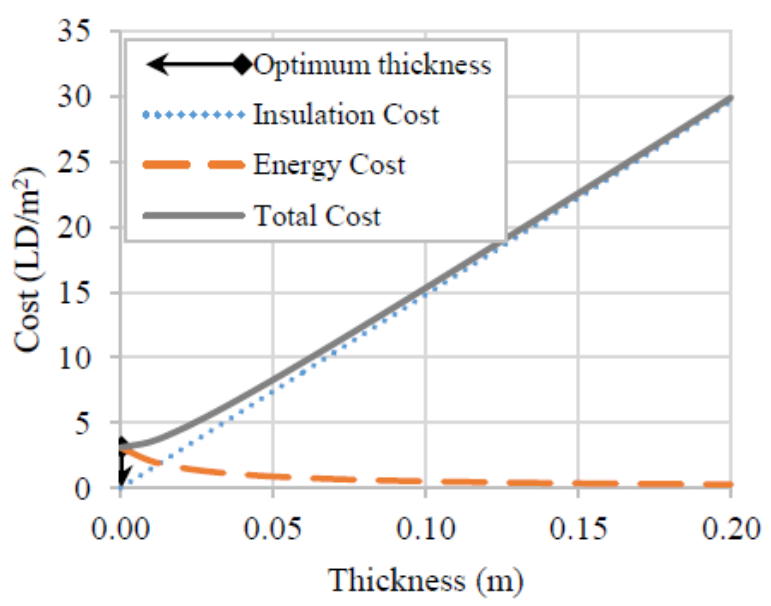

Fig. 6. Variation of cost with insulation thickness for case one 


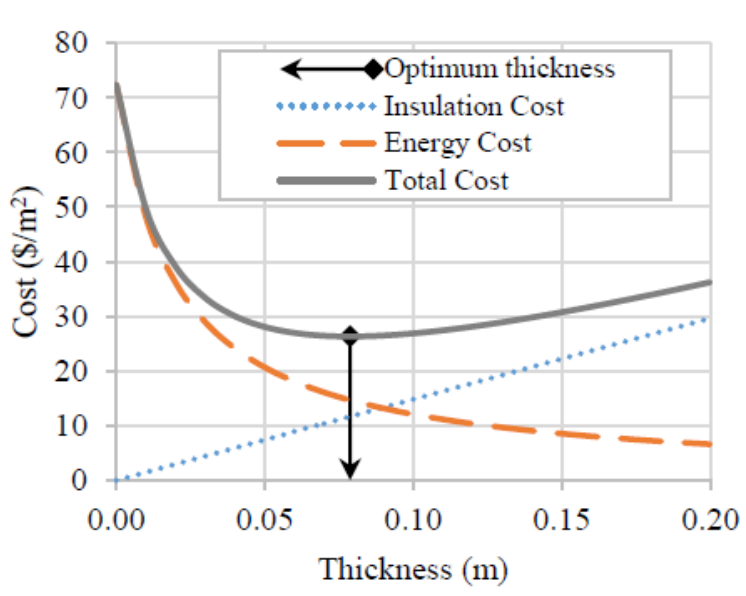

Fig. 7. Variation of cost with insulation thickness for case five

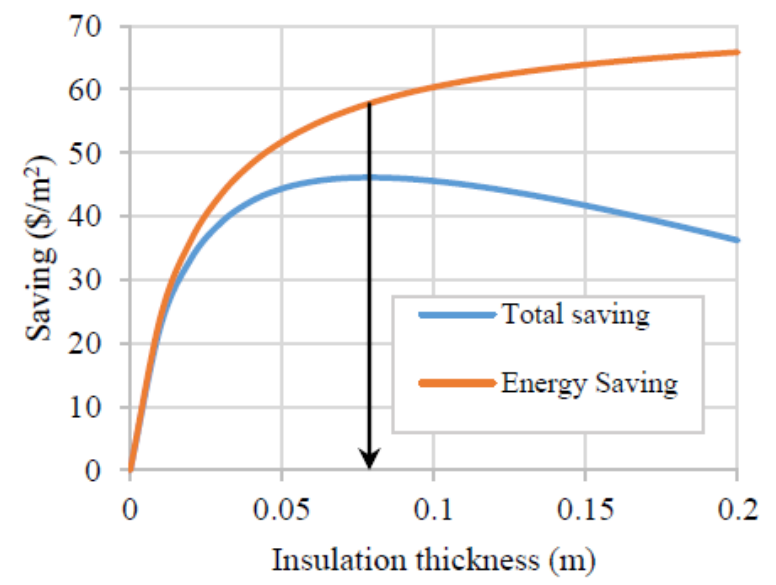

Fig. 8. Variation of cost saving with insulation thickness for case five

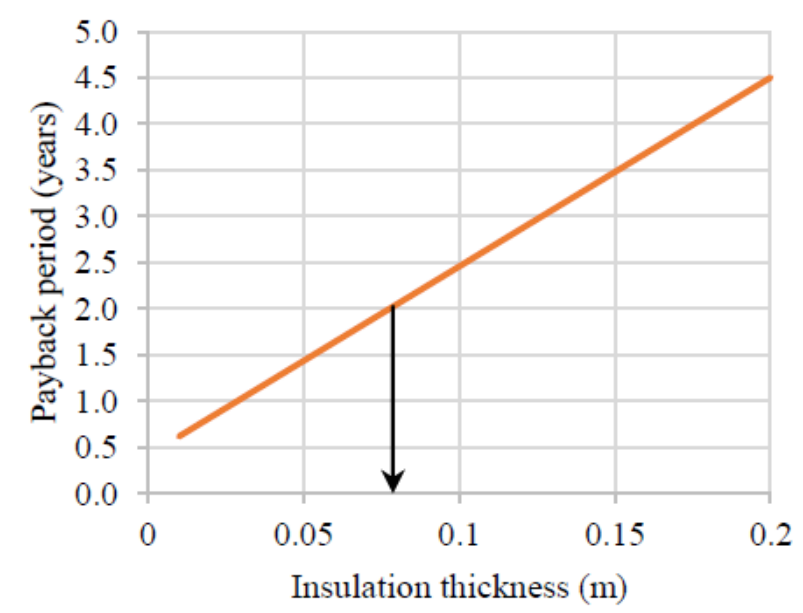

Fig. 9. Variation of payback period with insulation thickness for case five

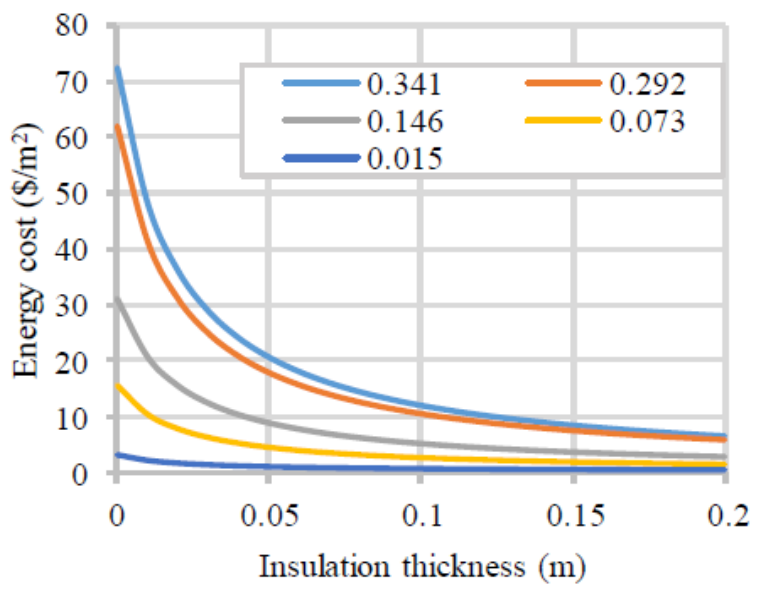

Fig. 10. Energy cost versus insulation thickness with different electricity prices

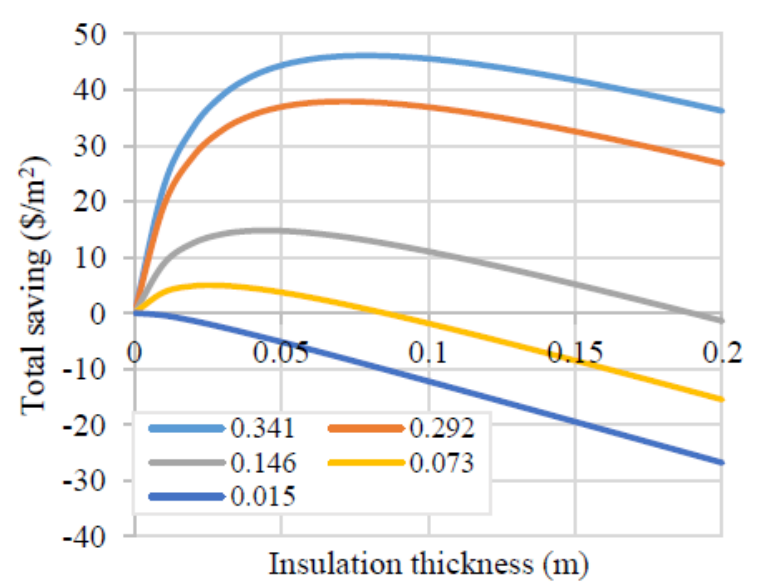

Fig. 11. Variation of total saving with insulation thickness at different electricity prices

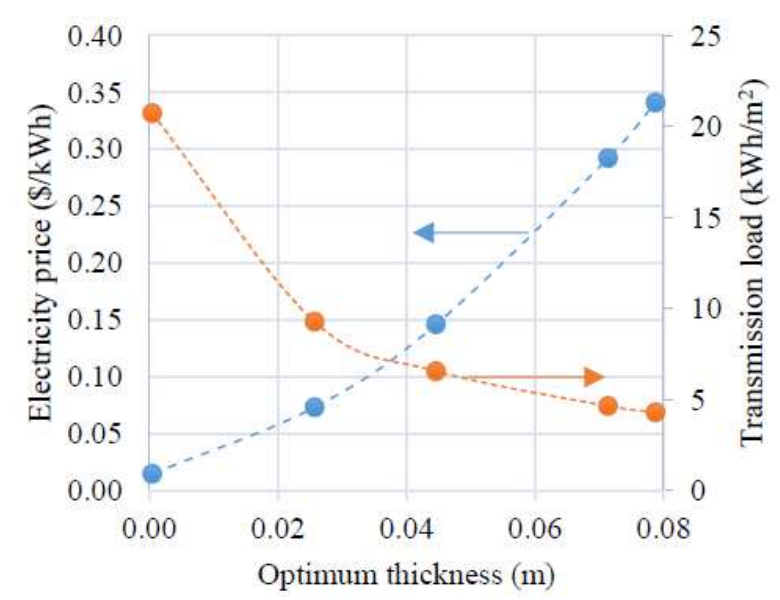

Fig. 12. Optimum thickness, versus electricity price and transmission loads 


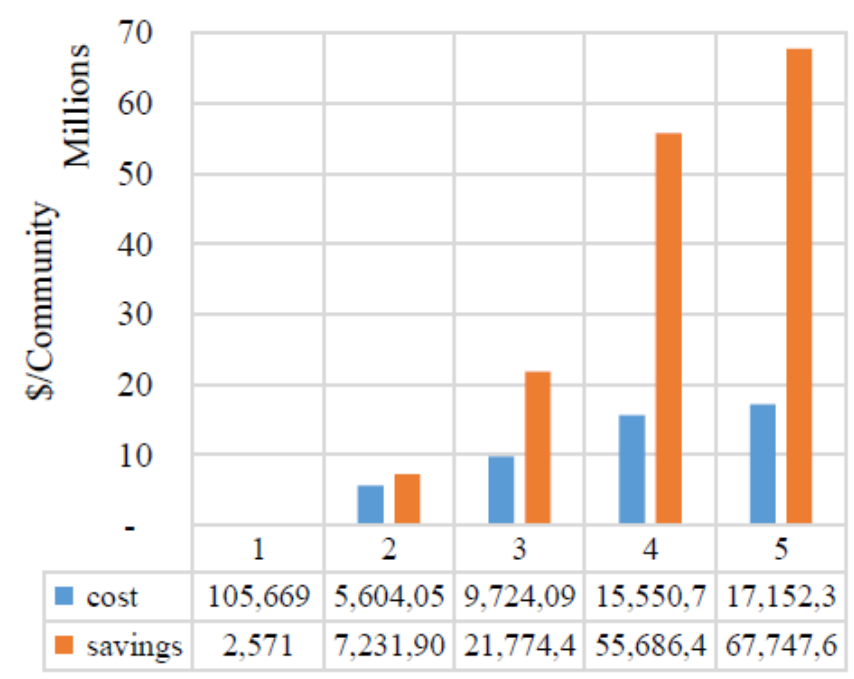

Fig. 13. Community energy saving for all cases

Table 2. The parameters used in this study

\begin{tabular}{|c|c|}
\hline Parameter & Value \\
\hline \multicolumn{2}{|l|}{ City (Tripoli-Libya) } \\
\hline CDD & $555^{\circ} \mathrm{C} \mathrm{d}$ \\
\hline HDD & $558^{\circ} \mathrm{C} \mathrm{d}$ \\
\hline External wall: $20 \mathrm{~mm}$ cement plaster & $0.604 \mathrm{~m}^{2} \mathrm{~K} / \mathrm{kWh}$ \\
\hline \multicolumn{2}{|l|}{$+200 \mathrm{~mm}$ hollow concrete brick } \\
\hline \multicolumn{2}{|l|}{ + $20 \mathrm{~mm}$ cement plaster, Rwt } \\
\hline \multicolumn{2}{|l|}{ Insulation (polystyrene) } \\
\hline Density, $\rho$ & $33 \mathrm{~kg} / \mathrm{m}^{3}$ \\
\hline Conductivity, $\mathrm{k}$ & $0.033 \mathrm{~W} / \mathrm{mK}$ \\
\hline Cost, $C_{\text {ins }}$ & $148 \$ / \mathrm{m}^{3}$ \\
\hline \multicolumn{2}{|l|}{ Electricity } \\
\hline Price & $0.015-0.341 \$ / \mathrm{kWh}$ \\
\hline Coefficient of performance, COP & 2.3 \\
\hline Energy efficiency rating, EER & 1.9 \\
\hline \multicolumn{2}{|l|}{ Financial parameters } \\
\hline Lifetime, LT & 10 years \\
\hline
\end{tabular}

Table 3. Optimization results for all cases

\begin{tabular}{llllrrr}
\hline$\#$ & CE $\$ / \mathrm{kWh}$ & Rins $\mathrm{m}^{2} \mathrm{k} / \mathrm{W}$ & xopt $\mathrm{m}$ & Es $\mathrm{kWh} / \mathrm{m}^{2}$ & $\mathrm{LCS} \$ / \mathrm{m}^{2}$ & PP years \\
\hline 1 & 0.015 & 0.0147 & 0.0005 & 0.5 & 0.0017 & 9.80 \\
2 & 0.073 & 0.7800 & 0.0260 & 12.0 & 4.9200 & 4.37 \\
3 & 0.146 & 1.3500 & 0.0450 & 14.7 & 14.8200 & 3.09 \\
4 & 0.292 & 2.1600 & 0.0710 & 16.6 & 37.8900 & 2.18 \\
5 & 0.341 & 2.3900 & 0.0790 & 16.9 & 46.1000 & 2.02 \\
\hline
\end{tabular}

The total saving based on the LCC analysis for all cases is shown in Fig. 11. For subsidized electricity price $\left(0.015 \$ / \mathrm{m}^{2}\right)$, the saving is always negative, i.e., the insulation is not feasible from economic point of view and any investment in this regard is considered a financial loss for individuals. By increasing the electricity price, the total saving increases per unit area and reaches a maximum of $46 \$ / \mathrm{m}^{2}$.

Figure 12 summarizes the relation between the optimum thickness and electricity prices and between the optimum thickness and the total transmission load. The optimum thickness increases from 0 to 0.079 with the electricity price in a parabolic manner, while the energy transmission load decreases from 21 to $4 \mathrm{kWh} / \mathrm{m}^{2}$.

\section{Rough Estimation of Community Savings}

The potential of savings is not equal across all buildings, however to give a better indication of the expected savings, a large community in Tripoli consisting of 10000 residential houses is considered. The 
average house floor-area is $150 \mathrm{~m}^{2}$ with an average external wall area of $147 \mathrm{~m}^{2}$. As illustrated in Fig. 13, the first case is the worst case with minimum expected saving. The saving for the second, third and fourth cases are 7.2, 21.8 and 55.7 Million Dollars, respectively. The fifth case's total annual saving is 67.7 Million Dollars. It is worth to emphasize that this amount of savings corresponds to a small community of the city of Tripoli. Therefore, irrespective of whether buildings need to be heated or cooled, employing insulations on exterior walls results in huge savings of government expenditure on energy production.

\section{Conclusion}

The effect of the electricity prices on optimum insulation thickness was studied in this study for the city of Tripoli. That is in order to highlight the amount of energy losses due to space cooling and heating from the external walls. The study showed that the current subsidized price of electricity does not encourage consumers to use thermal insulations in building walls for energy saving. However, when actual price was considered in the analysis, the amount of annual potential savings is found to be $16.9 \mathrm{kWh} / \mathrm{m}^{2}$ which is equivalent to $46.1 \$ / \mathrm{m}^{2}$. The results show that increasing the electricity price leads to increase in the thermal insulation thickness. In addition, apart from the subsidized price, all other prices considered in this study resulted in savings. The amount of savings was estimated for a community of 10000 houses to reach 67.7 million dollars. Therefore, the government can reduce spending money on energy production by finding alternative ways to implement wall insulation in buildings of the city of Tripoli. An urgent action that might be taken to save that energy is by enforcing a code of insulation nationwide at least on newly established buildings.

\section{Acknowledgment}

The authors would like to acknowledge, the staff of the Department of Mechanical and Industrial Engineering, University of Tripoli for providing general guidance and support in developing this work.

\section{Author's Contributions}

Authors had contributed at all stages including discussions, data collection, methods and results.

Samah K. Alghoul: organized the study, coordinated the data-analysis and interpretation of data and contributed to the writing of the manuscript.

Ammar O. Gwesha: Reviewed, contributed to the research plan, writing of the manuscript and analysis and interpretation of data.
Abdurrauf M. Naas: Contributed to data collection, analysis and interpretation of the data and to the writing of the manuscript.

\section{Ethics}

This article is original and contains unpublished material. All authors have read and approved the manuscript and no ethical issues involved.

\section{References}

Al-Homoud, M.S., 2005. Performance characteristics and practical applications of common building thermal insulation materials. Build. Environ., 40: 353-366. DOI: 10.1016/j.buildenv.2004.05.013

Al-Sallal, K.A., 2003. Comparison between polystyrene and fiberglass roof insulation in warm and cold climates. Renewable Energy, 28: 603- 611.

DOI: 10.1016/S0960-1481(02)00065-4

Al-Sanea, S.A., M.F. Zedan and S. Al-Ajlan, 2005. Effect of electricity tariff on the optimum insulationthickness in building walls as determined by a dynamic heat-transfer model. Applied Energy, 82: 313-330. DOI: 10.1016/j.apenergy.2004.10.014

ASHRAE, 1997. ASHRAE handbook: Fundamentals. American Society of Heating Refrigerating AirConditioning Engineers, Atlanta, GA.

Asan, H., 2000. Investigation of wall's optimum insulation position from maximum time lag and minimum decrement factor point of view. Energy Build., 32: 197-203. DOI: 10.1016/S0378-7788(00)00044-X

Bolattürk, A., 2006. Determination of optimum insulation thickness for building walls with respect to various fuels and climate zones in Turkey. Applied Thermal Eng., 26: 1301-1309. DOI: 10.1016/j.applthermaleng.2005.10.019

Çay, Y. and A.E. Gürel, 2013. Determination of optimum insulation thickness, energy savings and environmental impact for different climatic regions of Turkey. Environ. Progress Sustainable Energy, 32: 365-372. DOI: 10.1002/ep.11621

Daouas, N., 2011. A study on optimum insulation thickness in walls and energy savings in Tunisian buildings based on analytical calculation of cooling and heating transmission loads. Applied Energy, 88: 156-164.

DOI: $10.1016 /$ j.apenergy.2010.07.030

GECOL, 2012. Annual Report: Statistics. General Electricity Company of Libya, Tripoli.

Ghrab-Morcos, N., 2005. CHEOPS: A simplified tool for thermal assessment of Mediterranean residential buildings in hot and cold seasons. Energy Build., 37: 651-662. DOI: 10.1016/j.enbuild.2004.09.020 
Gürel, A.E. and A. Daşdemir, 2011. Economical and enviromental effects of thermal insulation thicness in four different climatic regions of Turkey. Int. J. Renewable Energy Res., 1: 1-10.

Gwesha, A., A. Naas and S. Alghoul, 2016. Determination of optimum insulation thickness of external walls in three Libyan cities on the basis of economic analysis of space heating (In Arabic Language). J. Eng. Res.

Hasan, A., 1999. Optimizing insulation thickness for buildings using life cycle cost. Applied Energy, 63: 115-124. DOI: 10.1016/S0306-2619(99)00023-9

Ozel, M., 2013. Determination of optimum insulation thickness based on cooling transmission load for building walls in a hot climate. Energy Convers. Manage., 66: 106-114.

DOI: $10.1016 /$ j.enconman.2012.10.002

Ozel, M. and K. Pihtili, 2007a. Investigation of the most suitable location of insulation applying on building roof from maximum load levelling point of view. Build. Environ., 42: 2360-2368.

DOI: 10.1016/j.buildenv.2006.05.006

Ozel, M. and K. Pihtili, 2007b. Optimum location and distribution of insulation layers on building walls with various orientations. Build. Environ., 42: 3051-3059. DOI: 10.1016/j.buildenv.2006.07.025

SEC, 2016. Electricity tariff. Saudi Electricity Company. SR, 2016. Electricity prices Europe 2014. Strorm Report.

NMC, 2014. Weather statistics. The National Meteorological Center, Tripoli.

Ucar, A. and F. Balo, 2011. Determination of environmental impact and optimum thickness of insulation for building walls. Environ. Progress Sustainable Energy, 30: 113-122. DOI: $10.1002 /$ ep. 10448

Wang, Y., Z. Huang and L. Heng, 2007. Costeffectiveness assessment of insulated exterior walls of residential buildings in cold climate. Int. J. Project Manage., 25: 143-149.

DOI: 10.1016/j.ijproman.2006.09.007

Yu, J., C. Yang, L. Tian and D. Liao, 2009. A study on optimum insulation thicknesses of external walls in hot summer and cold winter zone of China. Applied Energy, 86: 2520-2529.

DOI: 10.1016/j.apenergy.2009.03.010

Zaed, M. and K. Agha, 2012. The impact of energy pricing on renewable energy in deployment. Ministry of Electricity General Electric Company of Libya, Tripoli. 